REVIEW

\title{
Hospital planning for acts of terrorism and other public health emergencies involving children
}

\author{
S Chung, M Shannon
}

Arch Dis Child 2005;90:1300-1307. doi: 10.1136/adc.2004.069617

In today's world the increased potential of terrorist attacks places unique burdens and consequences on health care workers. Hospitals and hospital personnel must now be prepared to react immediately to such events. They must also implement, in advance, policies to protect their own health care personnel while providing care to victims. In this review, we discuss the four major forms of mass casualty terrorism (biological, chemical, nuclear, and thermomechanical) including clinical signs and symptoms for each, the impact on health care personnel, and special considerations for children. We will then outline key principles of hospital preparation with regard to paediatrics in anticipation of such emergencies.

See end of article for authors' affiliations

Correspondence to: Dr Sarita Chung, Division of Emergency Medicine, Children's Hospital Boston, Boston, MA 02115, USA; sarita.chung@childrens. harvard.edu

Accepted 28 July 2005
$\mathrm{T}$ he Merrimack Webster dictionary defines terrorism as "the systematic use of terror, especially as a means of coercion". The ultimate goal of terrorists may not be the greatest number of deaths but rather the maximum amount of fear and chaos caused by their acts.

Other motivations for terrorist acts include a desire for publicity or revenge or a wish to inflict injury. In the past, terrorists may have relied primarily on mechanical weaponry to achieve their goals, but with the advent of modern technology, they now have a larger array of modalities to meet their objectives. There is increasing recognition that biological, chemical, and nuclear weapons can be easily created, modified, and disseminated to an unsuspecting population. Such releases can be overt and dramatic or covert and fear inducing. Biological weapons are produced from either naturally occurring infectious agents (bacteria or viruses) or non-replicating toxins that are produced by living organisms including plants, animals, and microbes. These bacteria, viruses, or toxins can be modified (weaponised) to enhance their toxicity or virulence, thereby maximising disability after exposure. Chemical agents can be produced de novo, stolen from storage sites, or created from (ubiquitous) hazardous materials. Such chemicals, whether released intentionally or inadvertently, can cause significant morbidity and mortality. The threat from nuclear agents can arise from radiation release from a nuclear power plant, dispersal of radioactive material with conventional explosives ("dirty bomb"), a mishap occurring during transport, or even detonation of a nuclear device. The fourth category of mass casualty terrorism, thermomechanical (the destruction of large public buildings), brings its own unique medical complexities.

\section{WHY IS LONDON AT RISK?}

London, like many major metropolitan areas, has features that place it at significant risk of a terrorist attack as illustrated by the recent bombings in July 2005. The city has a population of approximately 7 million people in a densely packed area; a large scale terrorist attack could therfore result in high morbidity. Rich in historical architecture, the destruction of a major landmark, such as the Palace of Westminster, would be full of symbolic meaning and be psychologically disabling. Unfortunately, with the recent bombings on the London Underground (the Tube) and on a London bus, in which more than 50 people died, the London Underground, like many urban transport systems, has been shown to be a ideal site for terrorists as ventilation is poor and at peak traffic times there may be over 8000 commuters in a station at any one time. London is also the gateway to other cities in Europe and around the world. Following release, an infectious agent such as smallpox could be spread globally very quickly as London has five international airports and direct flights to over 59 destinations.

\section{THE SPECIAL NEEDS OF CHILDREN}

The physiological, anatomical, developmental, and psychological requirements of children differ from those of adults and create a need for understanding and special preparation by health care professionals. With a higher minute ventilation and a shorter stature (meaning they are closer to the ground), children will have increase exposure to aerosolised chemical and biological toxins. Due to a large skin to body mass ratio and less subcutaneous fat, children are at risk of sustaining more injuries due to transdermal toxins and hypothermia during skin decontamination with water. Having less fluid reserve, children can also develop early dehydration and shock after a food borne terrorist attack. Vital signs such as heart rate, respiratory rate, and blood pressure vary with children's age, thus health care providers need to be aware of this variability and recognise the normal ranges.

Abbreviations: BZ, 3-quinuclidinyl benzilate; Ca-DTPA, pentate calcium trisodium; CDC, Centers for Disease Control and Prevention; DMPS, dimercaptopropane-1. sulfonic acid; EMS, emergency medical services; KI, potassium iodide; RDD, radioactive dispersal devices; SARS, severe acute respiratory syndrome; Zn-DTPA, pentate zinc trisodium 
Treatment and resuscitation of ill children also vary by weight and need special consideration by health care providers.

Anatomically, the smaller mass and the pliability of a child's skeleton can result in greater multiple injuries after being hit by debris from a thermomechanical attack. For infants and toddlers, the mass of head to body ratio is larger than that of adults so they sustain more head injuries from flying debris after a terrorist bomb. This can add to medical complexity as head injuries are difficulty to assess in this age group.

Developmentally, children may have immature motor and cognitive skills. Depending on the age of the child, they may not be able to flee from danger (infant) or may actually run towards rather than away from a threat (toddlers and preschoolers).

Psychologically, after an event children are at risk of developing anxiety attacks, especially over separation from caregivers. They also have a greater risk of developing posttraumatic stress disorder and other enduring behavioural disturbances. $^{12}$

\section{BIOTERRORISM}

The US Centers for Disease Control and Prevention (CDC) has identified 35 potential bioweapons and placed them into the three following categories. ${ }^{3}$

\section{Category A agents}

Category A agents:

- Are easily disseminated or transmitted from person to person

- Result in high mortality rates and have the potential for major public health impact

- Possess the potential to cause public panic and social disruption

- Require special action for public health preparedness

- Provide the greatest risk to national safety

The six Category A agents are anthrax, smallpox, plague, tularaemia, the haemorrhagic fever viruses, and botulinum toxin. A summary of their clinical presentations and treatments is presented in table 1.

\section{Category $B$ agents}

Category $\mathrm{B}$ agents (table 2):

- Are moderately easy to disseminate

- Result in moderate morbidity rates and low mortality rates

- Require specific enhancements of CDC's diagnostic capacity and enhanced disease surveillance

\section{Category C agents}

Category $\mathrm{C}$ agents (table 2):

- Are emerging pathogens that could be engineered for mass dissemination due to availability

- Are easy to produce and disseminate

- Have potential for high morbidity and mortality rates and major health impact

Illness due to biological agents may be difficult to detect immediately because all agents have an incubation period ranging from a few days to months. Another difficulty with detection is that the initial symptoms of diseases due to biological agents may mimic other common respiratory illnesses such as influenza. While some diseases can be transmitted from person to person (pneumonic plague, smallpox) others cannot and the diseases they produce follow initial exposure (anthrax, botulism). Any bioweapon induced outbreak can easily cause panic and overwhelm hospitals and physician offices with patients who may or may not have been exposed.

Biological agents can be disseminated through the air by planes, in letters, or in ventilation ducts. Other potential methods of dissemination include contamination of food and/or water supply.

Children who are exposed to biological terrorism may present sooner to health care professionals as some agents have shorter incubation periods in children. Interestingly, after the Russian outbreak of inhalational anthrax in Sverdlovsk in 1979, there were no reports of increased morbidity or mortality in children. ${ }^{4}$ Health care providers may be hesitant to treat inhalational anthrax because of the theoretical risks with ciprofloxacin. While vaccines are available or are being developed for anthrax, plague, tularaemia, smallpox, botulism, Q fever, and Venezuelan equine encephalitis, only infant botulism and smallpox vaccine (above 1 year of age) are approved in children. ${ }^{5}$

The United States' recent experience with anthrax began on September 18, 2001, 7 days after the World Trade Center tragedy, when five letters containing anthrax bacteria were mailed to several news media offices and two US Senators. At least 22 cases of anthrax were reported in the following weeks. Eleven patients developed inhalational anthrax, and five of these victims died. The other 11 patients developed cutaneous anthrax but survived. ${ }^{6}$ Eight of the patients with inhalational anthrax had occupations that involved mail handling. ${ }^{7}$ The only child, a 7 month old infant diagnosed with cutaneous anthrax, had an atypical clinical course complicated by developing microangiopathic haemolytic anaemia and renal impairment. ${ }^{8}$ More than 32000 people were prescribed ciprofloxacin. ${ }^{9}$

\section{CHEMICAL TERRORISM}

When one considers the vast number of toxic chemicals used in modern society, many of which could be intentionally released on a population, it is not surprising that chemical weapons make up the largest cache in the terrorist's arsenal. Chemical agents are ideal for terrorists in that they are easy to manufacture, do not require complicated delivery systems, and cause instantaneous illness and confusion. Terrorists may manufacture chemical agents for mass destruction ("built weapons") or steal toxic chemicals from industry transport vehicles or storage sites ("weapons of opportunity"). While built weapons require time, resources, organisation, and money, weapons of opportunity require none of these and can, in fact, be released by a single individual at no financial cost. When exposed to chemical agents, children may present differently compared to adults. Following a nerve agent attack, CNS symptoms (weakness, hypotonia, seizures) may predominant without peripheral muscarinic effects being exhibited. ${ }^{10}$ A summary of the classes of chemical agents and their clinical presentations and antidotes is presented in table 3.

A comparison of the sarin incident of 1995 with a recent case of intentional food contamination, and their similarities with an unintentional hazardous materials incident is illustrated below.

On March 20, 1995, a religious cult released sarin gas into several subway stations during the morning peak rush hour in Tokyo, Japan. A total of 5000 victims, including 16 children, went to local hospitals; more than 4000 of these contaminated victims arrived by their own means. Subsequently, hospital workers were exposed to sarin gas and became symptomatic due to improper decontamination techniques and the entry of contaminated victims into hospitals. ${ }^{11}$ 
Table 1 Summary of the characteristics and management guidelines for category A biological weapons

\begin{tabular}{|c|c|c|c|c|}
\hline Agent & Incubation period & Syndromes and key features & Provider precautions & Treatment recommendations \\
\hline Anthrax & $1-60$ days & $\begin{array}{l}\text { Inhalational: fever, respiratory } \\
\text { distress with a widened } \\
\text { mediastinum, no rhinorrhea } \\
\text { Cutaneous: painless } \\
\text { swelling necrotic ulcer }\end{array}$ & $\begin{array}{l}\text { Standard universal } \\
\text { precautions }\end{array}$ & $\begin{array}{l}\text { Inhalational: IV ciprofloxacin } 20-30 \mathrm{mg} / \mathrm{kg} / \text { day } \\
\text { BID (max } 500 \mathrm{mg} / \text { dose) or doxycycline } \\
4.4-5 \mathrm{mg} / \mathrm{kg} / \text { day BID (max } 100 \mathrm{mg} / \text { dose) } \\
\text { and } 1-2 \text { additional antimicrobials* } \\
\text { Cutaneous: ciprofloxacin or doxycyclyne } \\
\text { (doses as above) }\end{array}$ \\
\hline Botulinum & $12-36 \mathrm{~h}$ & $\begin{array}{l}\text { Acute afebrile symmetric } \\
\text { descending flaccid paralysis, } \\
\text { multiple cranial nerve palsies }\end{array}$ & $\begin{array}{l}\text { Standard universal } \\
\text { precautions }\end{array}$ & $\begin{array}{l}\text { Supportive care (respiratory) and passive } \\
\text { immunisation with equine antitoxin }\end{array}$ \\
\hline $\begin{array}{l}\text { Haemorrhagic } \\
\text { fever viruses }\end{array}$ & 2-21 days & $\begin{array}{l}\text { Fever with progressive } \\
\text { haemorrhagic diathesis, } \\
\text { hypotension }\end{array}$ & $\begin{array}{l}\text { Patient isolation, } \\
\text { airborne/contact } \\
\text { precautions, personal } \\
\text { protective equipment }\end{array}$ & $\begin{array}{l}\text { Supportive care (attention to fluids } \\
\text { and electrolytes) and ribavirin } 30 \mathrm{mg} / \mathrm{kg} \\
\text { PO then } 15 \mathrm{mg} / \mathrm{kg} / \text { day BID }\end{array}$ \\
\hline Plague & $2-4$ days & $\begin{array}{l}\text { Pneumonic: fever, respiratory } \\
\text { distress with haemoptysis } \\
\text { Bubonic: fever and acute } \\
\text { swollen tender lymph node }\end{array}$ & $\begin{array}{l}\text { Patient isolation, airborne } \\
\text { precautions, personal } \\
\text { protective equipment }\end{array}$ & $\begin{array}{l}\text { Streptomycin } 15 \mathrm{mg} / \mathrm{kg} \mathrm{IM} \mathrm{q12h} \text { (max } 2 \mathrm{~g} \text { ) } \\
\text { or gentamicin } 2.5 \mathrm{mg} / \mathrm{kg} \mathrm{IV} \mathrm{q8h} \\
\text { Alternate: doxycyclyne, ciprofloxacin, } \\
\text { chloramphenicol }\end{array}$ \\
\hline Smallpox & 10-12 days & $\begin{array}{l}\text { Fever with vesicular rash } \\
\text { concentrated on face and } \\
\text { extremities (all lesions of } \\
\text { same age) }\end{array}$ & $\begin{array}{l}\text { Patient isolation, } \\
\text { airborne/contact } \\
\text { precautions, personal } \\
\text { protective equipment }\end{array}$ & $\begin{array}{l}\text { Vaccinia immune globulin } 0.6 \mathrm{mg} / \mathrm{kg} \mathrm{IM} \text {, } \\
\text { vaccina vaccine, cedofivir plus } \\
\text { probenacid** }^{*}\end{array}$ \\
\hline Tularaemia & 3-5 days & $\begin{array}{l}\text { Fever with } \\
\text { pleuropneumonitis }\end{array}$ & $\begin{array}{l}\text { Standard universal } \\
\text { precautions }\end{array}$ & $\begin{array}{l}\text { Streptomycin or gentamicin } \\
\text { Alternate: doxycyline, } \\
\text { chloramphenicol, ciprofloxacin }\end{array}$ \\
\hline
\end{tabular}

*Other antimicrobial agents include rifampin, vancomycin, penicillin, ampicillin, chloramphenicol, imipenem, clindamycin, and clarithromycin

**Smallpox vaccine is not recommended in children less than 12 months old.

On January 3, 2003, a Michigan supermarket in the United States issued a recall of approximately 1700 pounds of ground beef after customers complained of illnesses following its consumption. At least 111 people, including 40 children, developed a burning mouth, nausea, vomiting, and/or diarrhoea after eating the ground beef. Analysis of the meat showed evidence of nicotine, prompting concern that it had been intentionally contaminated. Upon further investigation, a grocery worker in the supermarket admitted to pouring a bottle of herbicide ( $40 \%$ nicotine) into 250 pounds of ground beef. He then packaged the beef and watched as customers bought it. The grocery worker was sentenced to 9 years in prison. This episode is one of the largest incidents of food borne chemical terrorism in US history. ${ }^{12}$

On January 6, 2005, a tank railway car carrying chlorine gas ruptured after a collision between two trains and emitted an estimated 11500 gallons of toxic gas. A total of nine people died and over 500 people were evaluated at local

\begin{tabular}{cl} 
Table 2 CDC category B and C agents \\
\hline CDC category B agents & Brucellosis (Brucella species) \\
& Epsilon toxin of Clostridium perfringens \\
& Food safety threats (Salmonella species, E \\
& coli 0157:h7, Shigella) \\
& Glanders and melioidosis (Bukholderia \\
& mallei and pseudomallei) \\
& Psittacosis (Chlamydia psittaci) \\
& Q fever (Coxiella burnetii) \\
& Ricin toxin from the castor bean \\
& Staphylococcal enterotoxin B \\
& Typhus fever (Rickettsia prowazekii) \\
& Viral encephalitis (alphaviruses, eastern \\
& equine encephalitis, western equine \\
& encephalitis) \\
& Water safety threats (Vibrio cholerae, \\
& Cryptosporidium parvum) \\
Nipah virus \\
Hantavirus
\end{tabular}

hospitals with ocular, skin, and respiratory complaints. Approximately 5400 people were evacuated from their homes due to high levels of chlorine gas. The tank was eventually sealed and the area cleaned, and most but not all residents were able to return to their homes after a week. ${ }^{13}$

In all cases, children were exposed along with adults. Each event caused a sudden surge in emergency room and doctor visits. Prehospital personnel may not be able to decontaminate all victims and hospitals will need to develop decontamination units so as not to cause secondary contamination to health care workers. Prehospital personnel also need to be aware of the vulnerabilities of children in order to efficiently decontaminate children so as not to cause further medical illnesses such as hypothermia. Hospitals that do not normally treat children, may need to consider paediatric protocols as families may be unwilling to separate and will need to be treated as a unit. Conversely, health care providers in children's hospitals will need to be trained to treat adults.

\section{NUCLEAR TERRORISM}

Civilian population exposure to radiation can result from a nuclear power plant event (accidental or intentional), the detonation of a nuclear weapon, an accident with a transport vehicle containing nuclear material, or the release of a radioactive dispersal device (RDD). RDDs ("dirty bombs") are made by combining nuclear material with a conventional explosive to allow for maximal dispersal of radiation. RDDs are currently considered the primary terrorist threat. This type of bomb produces few injuries but can result in long term environmental damage.

Children exposed to radiation are at a higher risk of developing radiation induced cancers, such as thyroid cancers. Having a greater minute ventilation, children are at risk of greater exposure to radioactive gases of all types. Radioactive iodine released by a nuclear bomb or power plant (but not an RDD) can be absorbed and secreted in human breast milk placing breastfed infants at unique risk since this may be their sole form of nourishment. ${ }^{14}$ 
Table 3 Chemical agents and their properties

\begin{tabular}{|c|c|c|c|c|c|}
\hline Mnemonic: & No & Victims & Can & Come & In \\
\hline Agent & Nerve & Vesicants & Choking & Cyanogens & Incapacitating \\
\hline Examples & Tabun, sarin, soman, VX & $\begin{array}{l}\text { Mustard gas, nitrogen } \\
\text { mustard }\end{array}$ & Phosgene & Hydrogen cyanide & $\begin{array}{l}\text { Cannabinoids, } \\
\text { barbiturates, 3- } \\
\text { quinuclidinyl } \\
\text { benzilate (BZ) }\end{array}$ \\
\hline Symptoms & $\begin{array}{l}\text { CNS (weakness, hypotonia, } \\
\text { stupor, coma), miosis, secretions } \\
\text { from nose and mouth, respiratory } \\
\text { distress }\end{array}$ & $\begin{array}{l}\text { Eyes: tearing, itch, burning } \\
\text { Skin: erythraemia, vesicles } \\
\text { Airways: rhinorrhea, cough, } \\
\text { dyspnea }\end{array}$ & $\begin{array}{l}\text { Cough, } \\
\text { dyspnea, } \\
\text { pulmonary } \\
\text { oedema }\end{array}$ & $\begin{array}{l}\text { "Cherry red" skin, } \\
\text { dyspnea, CNS } \\
\text { excitement } \\
\text { followed by CNS } \\
\text { depression (coma) }\end{array}$ & Delirium (BZ) \\
\hline $\begin{array}{l}\text { Provider } \\
\text { precautions }\end{array}$ & $\begin{array}{l}\text { Removal of clothes, } \\
\text { shower, personal protective } \\
\text { equipment }\end{array}$ & $\begin{array}{l}\text { Removal of clothes, } \\
\text { shower, personal protective } \\
\text { equipment }\end{array}$ & $\begin{array}{l}\text { Removal of clothes, } \\
\text { shower, personal } \\
\text { protective equipment }\end{array}$ & $\begin{array}{l}\text { Removal of clothes, } \\
\text { shower, personal } \\
\text { protective equipment }\end{array}$ & \\
\hline Antidotes & $\begin{array}{l}\text { Atropine } 0.05-0.1 \mathrm{mg} / \mathrm{kg} \text { IV IM } \\
\text { (max } 5 \mathrm{mg} \text { ); pralidoxime }>15 \mathrm{~kg} \\
\text { use } 600 \mathrm{mg} \text { autoinjector, }<15 \mathrm{~kg} \\
25-50 \mathrm{mg} / \mathrm{kg} \text { IV IM (max } 1 \mathrm{~g} \mathrm{IV} \text {; } \\
2 \mathrm{~g} \mathrm{IM}) ; \text { diazepam } \\
0.05-0.3 \mathrm{mg} / \mathrm{kg} \\
\text { (max } 10 \mathrm{mg} \text { ) }\end{array}$ & None & None & $\begin{array}{l}\text { Amyl nitrate } 1-2 \text { amps, } \\
\text { crushed, inhaled; } \\
\text { sodium nitrite ( } 3 \% \text { ) } \\
0.27-0.39 \mathrm{ml} / \mathrm{kg} \\
\text { (max } 10 \mathrm{cc}) ; \\
\text { sodium thiosulfate }(25 \%) \\
1.65 \mathrm{ml} / \mathrm{kg} \text { (max } 50 \mathrm{ml} \text { ) }\end{array}$ & $\begin{array}{l}\text { Physostigmine (BZ) } \\
0.02 \mathrm{mg} / \mathrm{kg} \mathrm{IV}, \\
\text { no faster than } \\
0.5 \mathrm{mg} / \mathrm{min}\end{array}$ \\
\hline
\end{tabular}

After exposure to radioactive iodines, potassium iodide (KI) is the recommended antidote, particularly for children. After ingestion, $\mathrm{KI}$ is taken up by the thyroid, preventing the incorporation of inhaled or ingested radioiodines. For maximum efficacy, KI should be administered immediately after an exposure, preferably within $8 \mathrm{~h}$. As there are only limited supplies of the liquid preparation of KI, health care workers or parents need to prepare solutions from crushed KI tablets. KI side effects are usually mild (rash or gastrointestinal symptoms) but can include hypothyroidism, especially in small children. Currently, the US Nuclear Regulatory Commission recommends providing KI to all citizens living within 10 miles of a nuclear power plant. The American Academy of Pediatrics recommends that KI should be stored in all schools and child care centres within such a radius. After exposure to radioactive iodines, KI only provides protection to the thyroid. ${ }^{14}$

Prussian blue has been approved for use in the US following exposure to cesium-137 and thallium. Prussian blue enhances the excretion of cesium-137 and thallium in the stool thereby decreasing radiation exposure, but does not treat complications from radiation. Dosage is $3-10 \mathrm{~g} /$ day PO $(0.21-0.32 \mathrm{~g} / \mathrm{kg} /$ day $) .{ }^{15}$

For plutonium, curium and americium exposure, treatment includes chelation with pentate calcium trisodium (CaDTPA), pentate zinc trisodium (Zn-DTPA), or dimercaptopropane-1-sulfonic acid (DMPS). Ca-DTPA and Zn-DTPA form stable chelates with metals and can then be excreted in the urine. Both Ca-DTPA and Zn-DTPA can be given by inhalation or intravenous access (dosage $14 \mathrm{mg} / \mathrm{kg}$ IV, max $1 \mathrm{~g})$, but may only be available in some hospital pharmacies and only in limited quantities during a mass exposure. DMPS has been shown to demonstrate protective effects when given as a pre-exposure prophylaxis and is available in oral and intravenous form under investigational new drug status. ${ }^{15}$

Radiation induced bone marrow suppression can be treated with epoetin alpha which induces erythropoiesis, filgrastim (a granulocye stimulating factor), or sargramostim (a colony stimulating factor). ${ }^{15}$

\section{THERMOMECHANICAL TERRORISM}

The tragic destruction of the World Trade Center towers in New York City by two hijacked planes on September 11, 2001 has provided painful yet necessary lessons for emergency preparedness officials and the medical community. In the first few hours, hospital emergency rooms closest to the scene received hundreds of patients arriving by foot with minor trauma or respiratory complaints in addition to ambulance arrivals of critical patients. In response, many hospitals in New York and throughout the north eastern United States initiated disaster preparedness plans in anticipation of providing medical care to large numbers of critically ill victims. Intensive care units and medical beds were opened. Surgical suites were staffed and put on standby. However, by that evening it became clear that while some people required specialised burn care, most of the victims had not survived.

The collapse of the buildings also created an intense mixture of dust particles which included asbestos, pulverised (highly alkaline) cement, glass fibres, polycyclic aromatic hydrocarbons, and polychlorinated biphenyls. A significant number of fire fighters and volunteers who participated in the rescue and recovery period developed a persistent cough with airway obstruction, now known as the "World Trade Center cough". This illness has been severe enough to require those suffering from it to take extensive medical leave longer than 4 weeks. ${ }^{16}$

The psychological effects of such terrorist incidents cannot be understated. One study showed that approximately $18 \%$ of New York City children had symptoms of severe posttraumatic stress. For school children in grades 4 through $12,27 \%$ met criteria for one or more of seven psychiatric disorders and reported problems in day to day functioning. ${ }^{17}$ Washington, DC also suffered a terrorist attack on September 11 when nearly 200 peopled died after a third hijacked plane crashed into the Pentagon. Researchers found elementary school children in Washington, DC continued to have serious negative reactions 3 months later, including symptoms of post-traumatic stress regardless of actual knowledge of a close friend or family member hurt in an attack. This study also showed a link between television exposure and negative reactions in children. ${ }^{18}$ Another report showed that 6 months after September 11, one or more of six probable anxiety/ depressive disorders were identified in $28.6 \%$ of all New York public school children. ${ }^{19}$ The need for mental health services continues, years after the event. 


\section{THE ALL HAZARDS APPROACH IN EMERGENCY PREPAREDNESS}

The US Federal Emergency Management Agency recommends an "all hazards" approach to emergency planning, an integrated plan that includes both terrorist acts and unintentional or natural public health emergencies. Such an approach optimises economic and organisational efficiency. For example, a response protocol for smallpox would be nearly identical to that created for an outbreak of severe acute respiratory syndrome (SARS); a chemical weapons response plan could be used after an unintentional hazardous materials release. Similarly, hospitals are now advised to prepare simultaneously for terrorist events as well as more likely public health emergencies such as hurricanes, tornados, hazardous materials incidents, and infectious outbreaks such as SARS. The premise behind this concept is that while causes of emergencies may differ, the potential effects of large scale public health emergencies are the same. Regardless of the incident or cause, victims will arrive at emergency units to be evaluated. Some will be very ill, while others, the so called worried well, may be fine but anxious and may request an evaluation. With this approach, each hospital should implement:

(1) A basic plan that overviews the hospital's emergency response organisation and policies (communication when a disaster happens, establishment of an emergency operation centre)

(2) Annexes to the plan that focus on specific emergency functions such as health and medical services (changes in triage of patients, role of mental health during the emergency)

(3) Hazard specific appendices that address the hazards which pose the greatest risk in that region as well as specific plans for bioterrorism, chemical, and nuclear attacks

(4) Standard operating procedure checklists that concretely provide step-by-step instructions and assign responsibilities to those in the emergency operations centre.

The clear advantage of this approach is a more centralised process to handling disasters of all types. ${ }^{20}$ As an example, the hazard specific plans currently used at Children's Hospital Boston are listed in table 4.

\section{Table 4 Hazard specific plans}

$\mathrm{P1}$ : Patient air system failure

P2: Brownout or electrical power shortage

P3: Blackout or electrical power outage

P4: Bomb threat

P5: Chemical spill

P6: Communications/telephone failure

P7: Computer system failure

P8: Earthquake

P9: Water incursion or flood

P10: Fire emergency

P1 1: Hostage

P12: Oxygen system failure

P13: Radiation spill/leak

P14: Steam system failure

P15: Vacuum/suction system failure

P16: Water supply problem

P17: Weather

P18: Evacuation/relocation

P19: Water contamination

P20: Fire annunciation/suppression failure

P21: Missing person

\section{RECOGNITION - THE ROLE OF SYNDROMIC SURVEILLANCE}

There is increasing focus on the development of methods to immediately detect an incident, whether it be the result of terrorism or an outbreak of a natural infectious disease such as influenza. With earlier recognition, morbidity and mortality may be reduced as a result of prompt intervention. Syndromic surveillance is a one method that allows for earlier detection. The term syndromic surveillance refers to techniques for monitoring the health complaints of individuals presenting to health care clinics and/or emergency rooms as a means of detecting an unusual illness pattern (cluster) or disease. In order to build syndromic surveillance systems, health complaints must first be grouped into categories such as respiratory, gastrointestinal, or neurological. In one technique, the total numbers of ill visits daily are compared to the historical average for that time of year. If the actual exceeds the anticipated number, an alarm could alert public health officials and physicians that an outbreak may be occurring. Currently, automated syndromic surveillance systems offer the dual function of not only identifying covert terrorist incidents but also detecting emerging infections such as West Nile virus or influenza. Surveillance systems can also incorporate geotemporal analysis, enabling the detection of clusters of illnesses in particular locations. ${ }^{21}$ Other systems have looked at the purchase of over the counter cold medications or school absenteeism. An example of such a system, in use at our facility, is given in fig 1.

Figure 1 shows AEGIS (the Automated Epidemiologic Geotemporal Integrated Surveillance system). AEGIS, developed by investigators in the Children's Hospital Informatics Program, detects abnormal patterns of disease in the region. The system operates fully in real time and in a completely automated fashion. Data are automatically and securely sent from emergency departments and clinics as soon as patients are registered. Cases are instantly appended to time series and plotted on maps, as shown. Advanced geotemporal clustering algorithms are applied to the data streams, comparing prevailing conditions with a normal baseline. When patterns of disease are abnormal (dark and pale grey zones at the top of the charts), an electronic message is sent to staff at Children's Hospital Boston, participating emergency departments, and local and state departments of public health.

\section{CONCEPTS IN PAEDIATRIC PREPAREDNESS}

\section{Paediatric treatment, medications, and vaccines}

Several challenges face hospitals, particularly children's hospitals, in planning for large scale disasters. The lack of existing paediatric protocols both for decontamination and for drug and vaccine administration has necessitated paediatric hospitals to create their own. Medications recommended for treatment of diseases caused by biological and chemical attacks, for example ciprofloxacin, smallpox vaccine, or pralidoxime, are either untested or not routinely given to a paediatric population. Dosages are weight dependent and need to be carefully monitored in order to prevent medication errors. In addition, many vaccines (anthrax, plague) are not available for children.

\section{Campus and personnel safety}

In order to provide optimal care for patients and remain functional, hospitals must first protect their own personnel. In the sarin attack in Tokyo, many health care providers become ill from secondary exposure due to lack of decontamination and proper protective equipment. ${ }^{11}$ As part of staff protection, hospitals must create sheltering-in ("lockdown") protocols in the event of a mass casualty incident with contaminated victims or environmental release of a 


\section{$\Lambda$ E G I S}

\section{HOME INVESTIGATE}
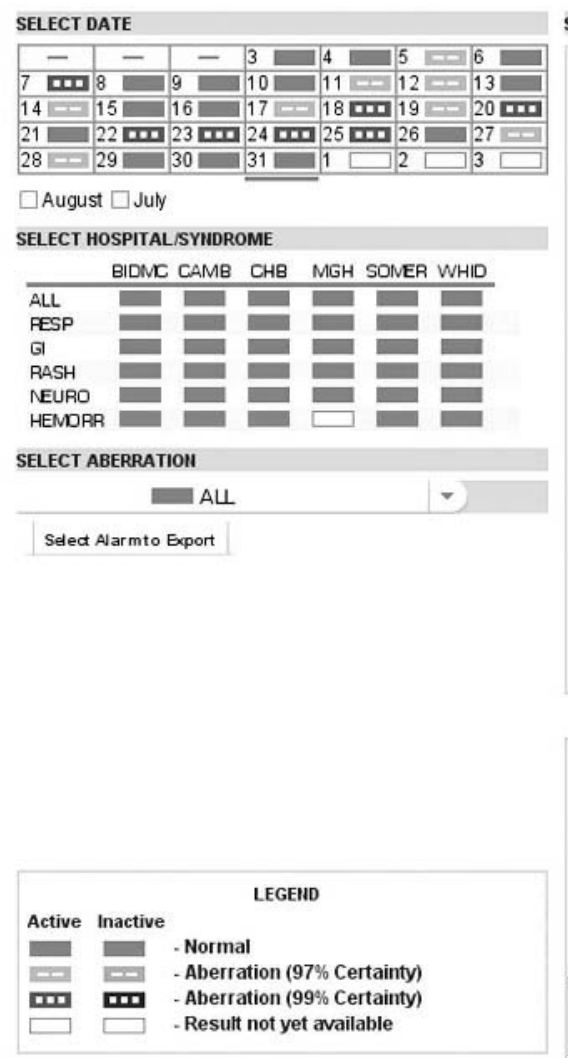

Viewing ALL visits at $\mathrm{CHB}$ for $\mathbf{8} / 29$.

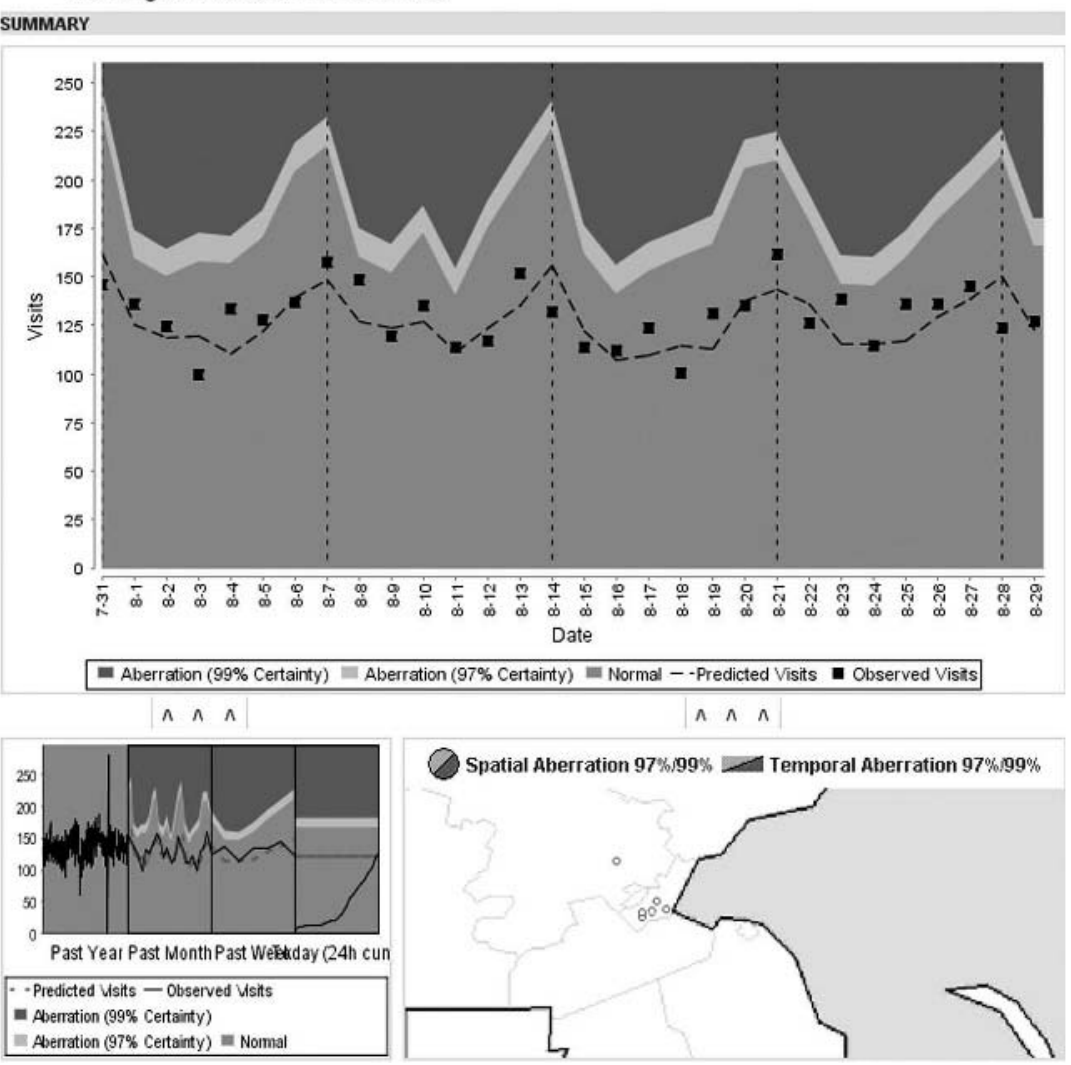

Figure 1 AEGIS screen capture. (Figure courtesy of Kenneth D Mandl MD, MPH).

dangerous substance. Such protocols are needed to prevent unauthorised entry and, if quarantine is required, unauthorised exit. To accomplish this, an inventory of all exits and entrances must be made and a mechanism for mobilising additional security forces to protect all entrances and exits must be in place.

\section{Personal protective equipment and decontamination}

Hospital based decontamination practices are different from the traditional methods employed in the field. For hospital personnel, potential exposure to chemicals results not from the released source but rather from proximity to and contact with the skin and/or clothing of contaminated victims. While how much protective gear hospital personnel should have is debated, at a minimum hospital staff should wear an encapsulated suit or a suit with junction seams sealed and a supplied air respirator to protect them from secondary exposure while decontaminating patients. ${ }^{22}$

To properly decontaminate patients, the hospital must use a designated area outside its facility. This area should be divided into the "hot", "warm", and "cold" (also known as red, yellow, and green) zones that are needed for safe decontamination. Simply removing clothes from patients accomplishes $85-95 \%$ of decontamination. Clothes must then be placed in an appropriate biohazard container. Ideally water for showering should be at $60 \mathrm{psi}$ and $37.8^{\circ} \mathrm{C}$ and after showering should be contained and placed in waste barrels in order to prevent environmental contamination. ${ }^{23}$ Non-ambulatory children will need assistance from health care workers and family members when undergoing decontamination. Health care providers will need to be sensitive to children's fears and developmental stage during the process so as not to exacerbate any mental health problems in the future.

\section{Surge capacity and alternative sites of care}

As seen after recent terrorist attacks, hundreds of victims can present to hospitals for care in the first hours after the incident. Prehospital emergency medical services (EMS) will not be able to care for all who are hurt at the scene. EMS disaster management principles of field decontamination, triage, and transport will be ineffective in large scale incidents, making hospital emergency units the first responders in a disaster. It is estimated that for every critical care patient, there will be five unaffected patients seeking treatment. ${ }^{23}$ Those who are ambulatory will try to come to the hospitals by any means possible, some by walking, others by private transportation. Hospitals need to evaluate their resources and determine how to respond to a disaster that could involve management of more than 500 casualties per million population. In preparation, hospitals should identify areas that can be converted into triage areas (for example, a lobby) and alternative care sites for the "walking wounded" (ambulatory clinics) and "worried well" (auditorium, conference rooms) in order to allow the emergency department to focus on critically ill patients. Hospitals should identify and create an inventory of all isolation, reverse ventilation rooms and areas that could be converted into temporary intensive care units and medical beds (postoperative care 
units, outpatient surgical areas). Hospital should also determine a protocol for when and how to mobilise extra staff. $^{24}$

Another important concept in surge capacity planning is "second wave" preparation. After a large scale disaster, less injured victims will reach the hospital first, usually by automobile or other individual transport. Critically ill victims will remain in the field longer, awaiting assessment and stabilisation. In the Tokyo subway sarin attack, one hospital received 500 patients in the first hour. ${ }^{11}$ Emergency units must be careful to allocate resources in a way that preserves their ability to care for late arriving, more critically ill patients.

Hospitals will also need to consider terrorist acts directed solely against children, such as a school bombing. In such cases, large numbers of children could present to hospitals for treatment. Hospitals that treat children may quickly overflow thus forcing hospitals that normally treat only adults to care for children with adult equipment.

\section{Terrorist events as crime scenes}

A concept foreign to health care professionals is the principle that terrorist events are acts of crime. Therefore, after an incident, all patients are considered to be crime victims. Consequently, during the decontamination process, clothes should be carefully labelled and preserved for evidence; they should also be closely monitored so as not to break the chain of custody. Law enforcement officials may have to enter hospitals to help gather evidence and interview patients, requiring the unusual but important presence of non-health care professionals in the midst of the treatment area.

\section{Medication stockpiling}

In order to protect hospital personnel and thereby maintain hospital functionality, medications for staff should be stockpiled. For example, antibiotics such as ciprofloxacin or doxycyline should be available so they can be rapidly distributed in case of an anthrax outbreak. Access to atropine and pralidoxime kits will decrease morbidity and mortality following exposure to nerve gas. Acquiring medications for hospital personnel will ensure that the staff will be able to continue to work without worrying about their own health. Recognising that staff may be reluctant or unwilling to work if they are concerned about their own families, recent protocols include plans to stockpile medications for both personnel and their family members. While this is an unusual paradigm shift in health care, it effectively addresses the prerequisites for hospital care for terrorist victims.

\section{Hospital personnel training and drills}

Because an outbreak can occur at any time, a sufficient core of trained staff (physicians, nurses, administration, security, and engineers) should be present on each shift so that the hospital respond to incidents $24 \mathrm{~h}$ a day. Initial training should be followed by regular drills and refresher courses. Multidisciplinary hospital drills that involve physicians, nurses, security, engineering, and occupational health specialist should be conducted to test the strengths and weaknesses of existing protocols. Hospital drills can range from treating mock patients to table top discussion ${ }^{25}$ and should also include children as victims or simulate an event where all victims are children. Adult health care providers should receive additional education in the event that they may have to care for children. Services who should participate in such drills are listed in table 5.

\section{SUMMARY}

Unfortunately in the current age, the threat of terrorism is real and may present in biological, chemical, nuclear, and thermomechanical forms. Each type of terrorism has its own
Table 5 Departments and staff participating in a hospital drill

Administrative support

Administrator on duty

Admitting

Blood bank

Coordinator of patient placement

Critical care

Emergency department

Emergency management

Engineering

Environmental services

Finance

Information services

Materials management

Medical records

Nursing administrator on call

Parking and transportation

Pastoral care

Pathology

Pharmacy

Public affairs

Radiology

Respiratory care

Safety

Security

Social work

Surgical services

Trauma program

unique medical illnesses and challenges with regard to children. An all hazards approach allows a hospital to build a framework for developing a disaster plan. Hospitals must now implement policies to protect their personnel while also caring for patients.

\section{ADDITIONAL RESOURCES ON THE WEB}

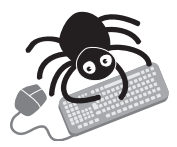

Additional resources available on the web concerning paediatric preparedness include: National Advisory Committee on Children and Terrorism to the US Secretary of Health and Human Services Final Report, CDC at http://www.bt.cdc.gov/children/PDF/ working/Recommend.pdf; Pediatric Disaster and Terrorism Consensus Conference: National Guidelines and Treatment Recommendations, Columbia

University National Center for Disaster Preparedness at http://www.ncdp.mailman.columbia.edu/ pediatric_preparedness.pdf; Emergency Medical Services for Children program at http://www.ems-c. org; and Child Traumatic Stress Network at http:// www.nctsnet.org/nccts/nav.do?pid = hom_main.

\section{Authors' affiliations}

S Chung, M Shannon, Center for Biopreparedness, Division of Emergency Medicine, Children's Hospital Boston, Department of Pediatrics, Harvard Medical School, Boston, MA, USA

This study was supported by grant no. 00-290-0020 from the Agency for Healthcare Research and Quality

Competing interests: none declared

\section{REFERENCES}

1 American Academy of Pediatrics. Chemical-biological terrorism and its impact on children: a subject review. Pediatrics 2000;105:662-70.

2 Henretig FM, Cieslak TJ, Eitzen EM. Biological and chemical terrorism. J Pediatr 2002;141:311-26.

3 Rotz LD, Khan AS, Lillibridge SR, et al. Public health assessment of potential biological terrorism agents. Emerg Infect Dis 2002;8:225-30.

4 Walker DH, Yampolska O, Grinberg LM. Death at Sverdlovsk: what have we learned? Am J Pathol 1994; 144:1135-41.

5 Cieslak TJ, Christopher GW, Kortepeter MG. Immunizations against potential biological warfare agents. Clin Infect Dis 2000;30:843-50. 
6 CDC. Summary of notifiable diseases - United States, 2001. MMWR Morb Mortal Wkly Rep 2003;52:1-1008.

7 Jernigan JA, Stephens DS, Ashford DA, et al. Bioterrorism-related inhalational anthrax: the first 10 cases reported in the United States. Emerg Infect Dis 2001;7:933-44.

8 Freedman $\mathrm{A}$, Afonja $\mathrm{O}$, Chang $\mathrm{MW}$, et al. Cutaneous anthrax associated with microangiopathic hemolytic anemia and coagulopathy in a 7-month-old infant. JAMA 2002;287:869-74.

9 CDC. Update: investigation of bioterrorism-related anthrax and adverse events from antimicrobial prophylaxis. MMWR Morb Mortal Wkly Rep 2001;50:973-6.

10 Rotenberg JS, Newmark J. Nerve agent attacks on children: diagnosis and management. Pediatrics 2003;1 12:648-58.

11 Okumura T, Suzuki K, Fukuda A, et al. The Tokyo subway sarin attack: disaster management, Part 2: hospital response. Acad Emerg Med 1998;5:618-24.

12 CDC. Nicotine poisoning after ingestion of contaminated ground beefMichigan, 2003. MMWR Morb Mortal Wkly Rep 2003;52:413-16.

13 CDC. Public health consequences from hazardous substances acutely released during rail transit - South Carolina, 2005; selected states, 1999-2004. MMWR Morb Mortal Wkly Rep 2005;54:64-7.

14 American Academy of Pediatrics. Radiation disasters and children. Pediatrics 2003:111:1455-66.

15 Columbia University Mailman School of Public Health National Center for Disaster Preparedness. Pediatric preparedness for disasters and terrorism: a national consensus conference. Available at http://

www.ncdp.mailman.columbia.edu/pediatric_preparedness.pdf (accessed June 1, 2005).
16 Prezant DJ, Weiden $M$, Banauch $\mathrm{Gl}$, et al. Cough and bronchia responsiveness in firefighters at the World Trade Center. N Engl J Med 2002:347:806-15.

17 Fairbrother G, Stuber J, Galea S, et al. Unmet need for counseling services by children in New York City after the September 11 th attacks on the World Trade Center: implications for pediatricians. Pediatrics 2004;113:1367-74.

18 Phillips D, Prince S, Schiebelhut L. Elementary school children's responses 3 months after September 11 terrorist attacks: a study in Washington, DC. Am J Orthopsychiatry 2004;74:509-28.

19 Hoven CW, Duarte CS, Lucase CP, et al. Psychopathology among New York City public school children 6 months after September 11. Arch Gen Psychiatry 2005;62:545-51

20 Federal Emergency Management Agency. State and local guide 101: guide for all-hazard emergency operations planning. Available at: http:// www.fema.gov/rrr/gaheop.shtm (accessed December 15, 2004).

21 Mandl KD, Overhage JM, Wagner MM, et al. Implementing syndromic surveillance: a practical guide informed by the early experience. J Am Med Inform Assoc 2004;11:141-50.

22 Hicks JL, Hanfling D, Burstein JL, et al. Protective equipment for health care facility decontamination personnel: regulations, risks and recommendations. Ann Emerg Med 2003;42:370-80.

23 U.S. Army Soldier and Biological Chemical Command. Guidelines for mass casualty decontamination during a terrorist chemical agent incident. Available at http://www 1.va.gov/vasafety/docs/July25-2000-DASHOCall.pdf (accessed December 15, 2004).

24 Hicks JL, Hanfling D, Burstein JL, et al. Health care facility and community strategies for patient care surge capacity. Ann Emerg Med 2004;44:253-61.

25 Hicks JL, Penn P, Hanfling D, et al. Establishing and training health care facility decontamination teams. Ann Emerg Med 2003;42:381-90.

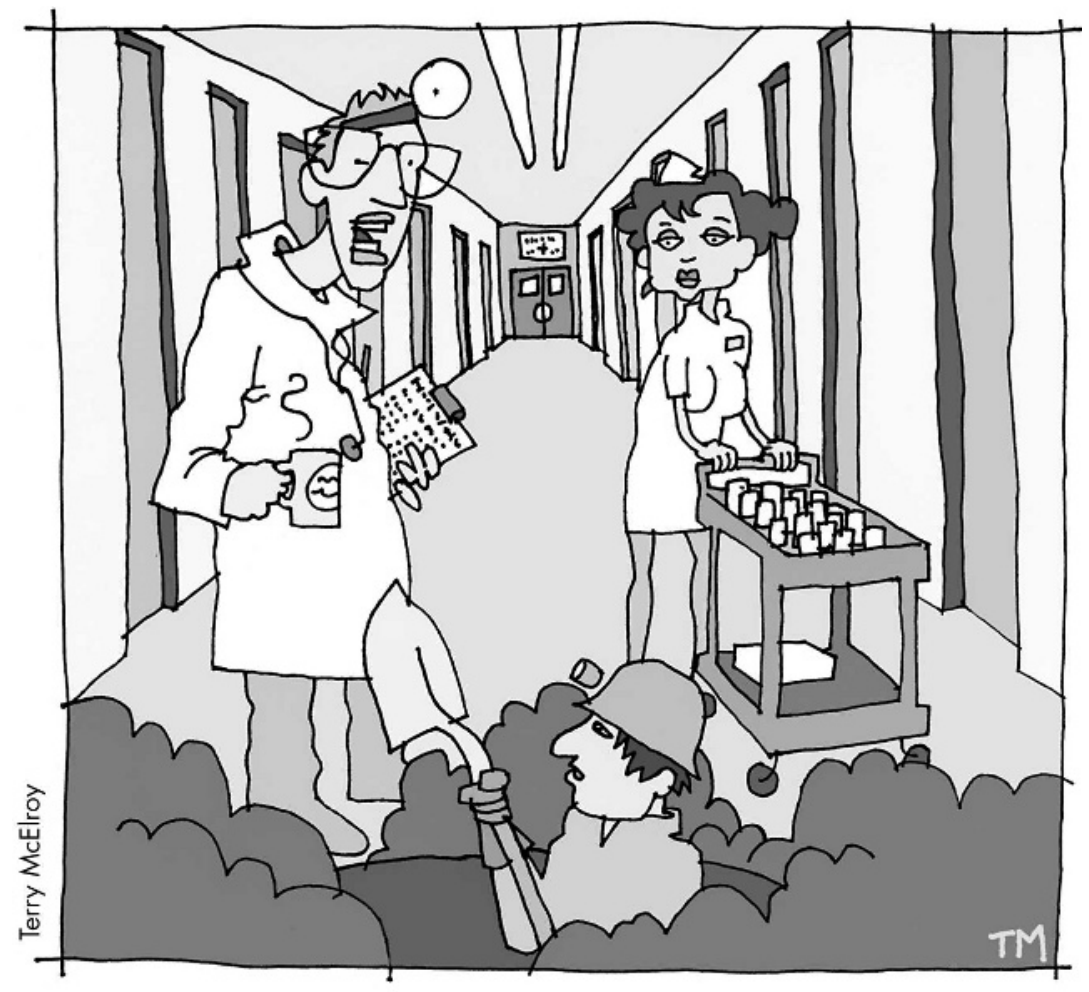

